\title{
Economic Development of the European Union in the Relation of Sustainable Development-Taxonomic Analysis
}

\author{
Janina Jędrzejczak-Gas, Anetta Barska *D and Joanna Wyrwa \\ Faculty of Economic and Management, University of Zielona Góra, 65-417 Zielona Góra, Poland; \\ j.jedrzejczak-gas@wez.uz.zgora.pl (J.J.-G.); j.wyrwa@wez.uz.zgora.pl (J.W.) \\ * Correspondence: a.barska@wez.uz.zgora.pl
}

Citation: Jędrzejczak-Gas, J.; Barska, A.; Wyrwa, J. Economic Development of the European Union in the Relation of Sustainable DevelopmentTaxonomic Analysis. Energies 2021, 14, 7488. https://doi.org/10.3390/ en14227488

Academic Editors: Iwona GorzeńMitka and Nuno Carlos Leitão

Received: 14 September 2021 Accepted: 3 November 2021 Published: 9 November 2021

Publisher's Note: MDPI stays neutral with regard to jurisdictional claims in published maps and institutional affiliations.

Copyright: (c) 2021 by the authors. Licensee MDPI, Basel, Switzerland. This article is an open access article distributed under the terms and conditions of the Creative Commons Attribution (CC BY) license (https:// creativecommons.org/licenses/by/ $4.0 /)$.

\begin{abstract}
The purpose of this paper is a multidimensional assessment of the diversification of economic development in EU countries in the context of the progress in the implementation of the concept of sustainable development in 2014 and 2019. The issues discussed in this article are topical and important, given that the spatial disparity of economic development in the EU has never been so pronounced as it is today. While there is a wealth of studies on economic development in the literature, research on the comprehensive approach to this problem in the relation of sustainable development appears to be rather scarce. The article emphasizes the role of energy in economic growth. Authors used taxonomic measures. They were constructed on the basis of selected methods of multidimensional comparative analysis. By using the Hellwig method and the TOPSIS method, taxonomic measures were constructed, and linear ordering of the EU countries was carried out. In addition, using the so-called threshold method, the clustering of EU countries was carried out. The analysis involved $27 \mathrm{EU}$ countries. The conducted research revealed significant disproportions between the respective EU countries in terms of the level of economic development in the relation of implementing the concept of sustainable development. It seems justified to take action aimed at eliminating the differences between the countries in the analyzed aspect. It is necessary both to intensify efforts at the level of individual Member States and the EU, oriented towards prodevelopment activities.
\end{abstract}

Keywords: economic development; sustainable development; energy; multidimensional comparative analysis; EU countries

\section{Introduction}

Sustainable development is the overarching goal of the European Union (EU), leading towards economic growth, EU citizens' prosperity, and a higher quality of life for present and future generations [1]. The concept of "sustainable development" is proposed by the Brundtland Commission as a "development that meets the needs of the present, but does not jeopardize the ability of future generations to meet their personal needs" [2] American economist Donella Meadows (as cited in [3]) notes that the world population is doubling approximately every 40-50 years. At the same time, however, the planet, which provides the energy and materials necessary for the functioning of society and economy, cannot increase its resources. In addition, along with the world's growing population and economic development, the global demand for increasingly scarce energy resources continues to rise, and the global economy is threatened by a growing energy deficit and hence also a significant degradation of the natural environment. The concept of sustainable development, which is the basis of ecological economics, assumes that subsequent economic development can only take place within the limits of nature's tolerance. Thus, attention is drawn to the need for selective economic development, marked by an increased role of some sectors (such as renewable energies or R\&D) and a diminished role of others (such as those relying on conventional energy sources), improving efficiency, coherence of 
operation, and sufficiency of natural resources, including energy [4]. Broadly, it means a development that takes into account economic, social, and environmental aspects, balancing out their importance in a sustainable way. Hence, a responsible and forward-looking energy policy is an important driver of sustainable development, with access to energy sources being one of the prerequisites of economic development [5-13]. The conditions of access to energy, the cost of obtaining it, and the lack of an energy substitute are factors influencing sustainable development and the rate of economic growth. The implementation of sustainable development in the area of energy is expected, among other outcomes, to increase the efficiency of energy consumption, rational management of natural resources, and reduction of waste, including $\mathrm{CO}_{2}$ emissions. Long-term forecasts of global energy consumption indicate the possibility of a 2.5-3-fold increase in energy consumption in 2050 compared to 2010 [14]. Therefore, the effective management of energy carriers in the economy is of pivotal importance for sustainable development, and the significance of energy as a factor limiting sustainable development is bound to increase.

The EU has for years been engaged in sustainable activities and has made attempts to outline a European strategy for sustainable development. The strategy is based on measures to ensure energy security and improve economic competitiveness. It is assumed that the objectives of the EU energy strategy will be met while ensuring safe and uninterrupted energy supplies at an acceptable price and in an environmentally friendly manner. The EU energy policy focuses mainly on three areas: renewable energy; reducing harmful pollutant emissions, in particular $\mathrm{CO}_{2}$; and increasing energy efficiency [15]. If implemented successfully, the policy should propel the EU towards lower consumption, and a safer and more competitive economy based on sustainable energy. Meeting these targets is expected to contribute to transforming Europe into a more efficient economy marked by low $\mathrm{CO}_{2}$ emissions. In turn, it will usher in a new industrial revolution, quickening the transition to low- $\mathrm{CO}_{2}$ economic development, and in the future, to an increase in the production and consumption of low-emission locally sourced energy.

In relation to energy management, sustainable development consists of the optimal use of energy resources to ensure sustainable economic and social development in line with environmental requirements. A sustainable energy policy primarily includes the principle of rational use of energy, which helps improve energy efficiency, protect the environment, and increase energy security [16]. It envisages integrated energy action for both energy supply and demand, using state-of-the-art technologies that favor the environment and improved quality of life [17].

The aim of this presented study is a multidimensional assessment of the diversification of economic development in EU countries in the context of the progress in the implementation of the concept of sustainable development in 2014 and 2019. The issues discussed in this article are topical and important, given that the spatial disparity of economic development in the EU has never been so pronounced as it is today. While there is a wealth of studies on economic development in the literature, research on the comprehensive approach to this problem in the relation of sustainable development appears to be rather scarce.

The problem area of sustainable development has been met with great interest among researchers, as evidenced by the constantly growing number of scientific papers devoted to various issues related to this subject [18-28]. An overall positive approach to this concept of development tends to be predominant in the literature, although this is not to say voices of criticism are not there, especially as the very definition of sustainable development is controversial. Despite many attempts having been made over the years, scholars have so far been unable to work out a clear interpretation of this term [29-32]. Sustainable development is not a uniform strictly demarcated category, but rather a fluid concept that changes its scope and reflects different value systems over time and in space. Nevertheless, despite its ambiguity, certain common elements can still be identified, such as a long-term horizon in relation to the principles of environmental protection, careful management 
of natural resources, and precautionary measures towards natural capital guided by the principles of justice [33].

The multidimensional nature of sustainable development, which translates into different ways of interpreting this concept, the lack of an unambiguous definition and the complexity of the problem area that it encompasses, make it difficult to gauge and compare relevant research findings. Therefore, the assessment of the progress of EU countries in implementing the economic governance in the context of sustainable development requires the selection of an appropriate set of indicators. For a long time, there has been a discussion in the literature on the measurement of sustainable development and the choice of commonly accepted indicators [34-47] by identifying a number of prerequisites in relation to the adopted variables. These should be relevant for the purpose of the study and consistent with the adopted definition of sustainability, measurable, define all areas of sustainability, independent of each other, and non-duplicating in terms of the conveyed information, as well as being reliable and easily accessible, up to date, and regularly updated [48]. The use of a set of statistical benchmarks allows for a comprehensive coverage of numerous thematic areas that make up the concept of sustainable development in the context of national and regional policy, while ensuring the possibility of their in-depth analysis in selected topics. The sets of indicators enable not only the assessment of the current state, but also the formulation of measurable goals, monitoring of the changes taking place, and evaluation of the effects of the decisions and actions being made along the way [49]. The following criteria were used in selecting indicators for this economic-dimension study: presence on the list of indicators for monitoring the implementation of the EU Sustainable Development Strategy, international comparability, data availability, and credibility of the data source.

Two annual reports were analyzed in the research procedure for comparative purposes: one of 2014 (first year when the data is available for all 27 EU countries, after including Croatia) and the other of 2019 (for which the latest values of the analyzed indicators are available for all $27 \mathrm{EU}$ countries). The nature of the problem favored the choice of the following research methods: literature and strategic documents analysis, descriptive statistics, and multivariate analysis.

Economic development is a complex category due to this fact the authors used taxonomic measures and constructed them based on the selected methods of multivariate comparative analysis. The taxonomic measures were constructed on the basis of the suggested partial indicators, which were divided into the five thematic areas: (1) economy, (2) production and transportation patterns, (3) innovation, (4) energy patterns, and (5) employment. The indicators describing the individual areas provide an overview of the EU's progress towards sustainable development in terms of economic goals, taking into account energy concerns.

In our opinion, these indicators best reflect the economic development and the idea of sustainable development in the EU. Applying taxonomic measures, which replaced the description of the studied objects (EU countries) with the use of a number of partial indicators with a description using one aggregate quantity, made it possible to measure the multidimensional phenomenon of economic development within respective EU countries, and also allowed for linear ordering of the examined objects (EU countries).

The first part of the article focuses on issues related to defining and measuring economic development presented in the literature. The second part presents the methodology and characterizes the results of the research. The authors used the TOPSIS method and the Hellwig method. They constructed taxonomic measures and performed linear ordering of the EU countries. Application of the two taxonomic methods is some kind of "confirmatory analysis" and allows the results to be compared. In addition, using the so-called threshold method, the clustering of EU countries was carried out. The analysis involved 27 EU countries. The selection of partial indicators was made on the basis of the following criteria: content-related, statistical, and formal (mainly relevance, completeness, and availability for all 27 EU countries in 2014 and 2019). 


\section{Assessing the Level of Economic Development: Review of the Literature}

Economic development is one of the pillars of sustainable development, spanning three main areas: economic, meaning the pursuit of a sustainable economy; social, meaning protection of public health, education, and social integration; and environmental, meaning an emphasis on the protection of the environment and natural resources [50]. Let us note that economic growth, social progress, and environmental order should be viewed as interdependent phenomena, which implies the need for a synergistic problem-solving approach on the path towards sustainable development [51,52]. Economic development is a long-term process that takes into account changes in the economy. It includes quantitative changes in basic macroeconomic values and qualitative changes in the socio-economic system as well as the organization of society $[53,54]$ The quantitative dimension is equated with the concept of growth in relation to production, employment, investment, the size of functioning capital, income, consumption, exports and housing resources, and other economic quantities characterizing the economy from the quantitative point of view. Energy is a factor in economic growth, and one seen by many governments as a strategic good [55]. The development of the energy sector brings tangible economic effects, as the increase in electricity prices for end users is counterproductive to the economy and curbs the activity of energy-intensive industries [56]. The use of renewable energy resources is one of the essential components of sustainable development, marked by clear economic, environmental, and social benefits. The EU's 2020 assumption was to achieve $20 \%$ of the final gross energy consumption from renewable sources [57]. The implementation of EU provisions in the area of energy efficiency is to improve energy security, counteract climate change, and should also have a positive impact on the economy through the promotion of market growth, new services, and innovative energy technologies.

From the qualitative perspective, economic development is expressed in transformations in the organization of society and the economy of a structural nature, which include, in particular, technical and technological progress, improvement of the intra-economic system and with the world economy, increase in the qualifications of the workforce, changes in the structure of the economy aimed at its modernization, increase in the level of effectiveness on a micro- and macroeconomic scale, as well as the emergence of new products and improvement of the existing ones. The high economic growth rate requires increased participation in the economy of innovative products and services. The condition for this is to ensure energy security [58].

According to Lange [59], economic development is growth in the productive forces of society. It contributes by increasing the quality of goods and services that satisfy human needs, an increase in wealth and prosperity. An analogous definition of economic development was put forward by Myrdal [60], who assumed that such development meant growth changes in the entire social system, including factors, such as production conditions, productivity and income, quality of life, attitudes towards the way of life, and work. Thus, economic development means changes in the structure of the production potential of the economy, the structure of production and consumption, socio-economic relations, and the system of functioning of the economy [61]. In contemporary terms, economic development is understood as a process of positive changes in the production and redistribution of goods and services, and their exchange and use for consumption purposes, increasing the economic potential of the state [62]. The study provides evidence of long-term and causal relationships between energy consumption and economic growth. Limited access to modern energy services could impede economic growth and compromise the development prospects of countries [63].

In the literature, economic development is generally identified as a long-term and multifaceted process $[64,65]$ relating to transformations not only in the entire economic system, but also within the social realm [66], and even in the natural environment [67]. It concerns targeted and lasting changes taking place in the field of all economic activity, as well as in the social, socio-productive, and political relations. The utilization of renewable energy resources is one of the essential components of sustainable development, producing 
tangible economic, environmental, and social effects. Growing the share of electricity from renewable energy sources in the internal electricity market has become an important objective of the European Union [56].

In the theory of economics, apart from the concept of economic development, there is also the definition of economic growth. The terms development and economic growth are clearly distinguished [68]. Growth is a quantitative category, understood only as multiplication, increasing the number, while development denotes structural changes [69]. Economic development, as a broader concept, includes economic growth, which presents quantitative changes in management and all kinds of qualitative and structural changes resulting from the progress of civilization [53]. Economic development is defined as the process of transition from a specific state to a more complex or advanced form, while economic growth is defined as the increasing capacity of a given society to produce goods and services that meet human needs. Economic development is understood as the process of transformation of economies with low national income into modern economies, and economic growth means the process of increasing national wealth over time and refers only to the measurable sphere of the economy (after $[70,71]$ ). In the literature on the subject, the dominant view is that development is impossible without economic growth [72].

The traditional approach to the factors of economic development most often includes property (capital) resources, natural environment, and demographic resources, which create more or less favorable conditions for the location of various economic activities. Systemic changes, the transformation of the economy, as well as scientific and technological progress have resulted in completely new conditions for economic development. In addition to traditional factors, there are the so-called modern determinants of development, such as economic potential, including the structure of the economy and its ability to transform, as well as social potential, which emphasizes the importance of social predispositions to progress and innovation, and the efficiency of the economic system [73].

Knowledge about the nature of development changes is necessary both to describe the current state of the area under scrutiny (diagnostic utility) as well as to make economic decisions (prognostic utility), both in the micro- and macroeconomic dimension. Identification of the nature of economic changes in a given specific area requires that they are measured. Economic development is a measurable category, but due to the complex nature of the phenomenon, it cannot be measured directly [74]. Economic development at the country level can be measured with both individual and aggregated indicators. The problem of measuring the level of economic development is widely discussed in the literature [75-81]. The effect of this is a large diversity in the methods of its measurement and the list of measures used in international comparative studies. Oftentimes, the discussion on this topic focuses not on the question of the best measure of measures, but on the determination of a synthetic measure. In many studies, the amount of gross domestic product (GDP) is adopted as such a measure. The use of GDP (including GDP per capita) as a synthetic measure of the level of economic development raises many reservations, e.g., due to the fact that the production of various goods and services, including the redundant or harmful ones, is included in GDP, and the differences in the distribution of income within the analyzed countries is ignored [82-86]. However, despite the fact that GDP has many disadvantages, it is still frequently used in assessing the level of economic development. It is assumed that the task of GDP is not to accurately measure long-term economic and social progress, including the ability of a given society to solve problems related to, inter alia, climate change, resource efficiency, and social integration [63].

The reservations about the measures of the level of development based on GDP led to the construction of more complex measures, using certain sets of indicators and an algorithm for combining them into one synthetic measure. In an attempt to eliminate the disadvantages of traditional measures based on the system of national accounts, efforts were made to modify them to take into account the qualitative aspects of the standard of living. Modified national accounts provide a bridge between conventional measures of economic development and indicators of sustainable development. Thus, economic 
development can also be measured with indices describing economic welfare and with indicators related to the category of sustainable development. It should be emphasized that the inclusion of the concept of sustainable development in the construction of the synthetic measure means that it should include additional categories, such as social and environmental order (more in: $[51,52,87,88]$ ). Access to modern energy is believed to be a prerequisite for sustainable development, poverty alleviation, and the achievement of the Millennium Development Goals [12]. The most famous measures used to compare economic development are the Measure of Economic Welfare, AnNet National Welfare, Index of Sustainable Economic Welfare, Net National Welfare, Index of the Economic Aspects Welfare, Index of Economic Freedom, or Genuine Progress Indicator (after [70]).

However, the literature often indicates that the modified national accounts are also burdened with various problems. Therefore, more and more often, national accounts are replaced with multifaceted measures that take into account various qualitative dimensions of economic development. Examples of such measures include the Geneva method or the Human Development Index. These measures are called synthetic indices or taxonomic measures. The greatest difficulty in constructing these measures is determining the elements that are to be included in them and assigning them an appropriate rank. A common complaint against taxonomic measures of economic development is that they devote too much attention to the qualitative components of prosperity, while overlooking its quantitative dimension. Therefore, the construction of appropriate synthetic indicators remains an open research problem, and the existing indicators should be verified and updated, taking into account new concepts of assessing the level of economic development, statistical data resources, and experiments with the use of existing indicators.

\section{Materials and Methods}

Economic development is a complex and multidimensional process. Of course, many different indicators can be used to evaluate it. However, the problem of correct assessment appears when some of the indicators point to positive changes, while others to negative ones. Therefore, in this study, the methods of multivariate statistics were used, which allow for the determination of a taxonomic index that replaces a set of many indicators with one aggregate index. The literature presents many different methods of constructing taxonomic indicators, which can be divided into two groups: (1) non-standard (model-free) methods, and (2) standard (model-driven) methods. In the former, the synthetic index is determined mainly by operating on the normalized values of partial indexes. In the latter, a reference (model) object is determined, against which, when calculating taxonomic distances, the distance for all tested objects is calculated.

In this study, taxonomic measures were used, construed on the basis of the two historically oldest methods of linear ordering, namely Hellwig's method and the TOPSIS procedure.

Economic development is a complex category. Therefore, it was decided that taxonomic measures would be used in this study, the two historically oldest methods of linear ordering, i.e., the Hellwig method and the TOPSIS method. Both methods are exemplary but have been developed in two different research areas. The first method was put forward by Hellwig in the field of economics in 1968 ("measure of economic development") [89]. The other method was suggested by Hwang and Yoon based on the decision theory in 1981 (TOPSIS) [90]. Even though both methods are exemplary, Hellwig's method uses as the reference point a pattern, while Hwang and Yoon's method uses a pattern and an anti-pattern. The normalization of partial indicators differs in both methods: standardization in Hellwig's, and zero-unitization in Hwang and Yoon's. The analytical form of the aggregation function is also different, where the obtained values of the synthetic measure are generally in the range [0;1] in Hellwig's method, and in the range [0;1] in Hwang and Yoon's. The simultaneous use of different reference methods is a kind of "confirmatory analysis" and enables a comparison of the results. The calculations were performed using Excel.

The procedure of constructing taxonomic measures consisted of several stages. 
Stage 1: Determination of a set of partial indicators. Using the substantive and formal criteria, a set of 28 partial indicators was determined (the aspects indicated in the EU Sustainable Development Strategy as well as the significance of the partial indicators and their availability were taken into account). The partial indicators were divided into five thematic areas: economy, production and transportation patterns, innovation, energy patterns, and employment (Table 1). The presented thematic areas were selected based on the assumptions and goals concerning the challenges of sustainable development set out in the EU strategic documents, namely: A European Union strategy for sustainable development [91], Europe 2020-A strategy for smart, sustainable, and inclusive growth [92]. The analysis also took into account the documents adopted at the conference in Rio de Janeiro, which was the key event for the implementation of the concept of sustainable development (mainly documents, such as Agenda 21 [93], the Rio Declaration on Environment and Development [94]) and the Post-2015 Development Agenda entitled "Transforming Our World: The 2030 Agenda for Sustainable Development" [95-98]. The resolutions adopted at other similar events also played an important role in the formulation of the five studied areas: The World Summit on Sustainable Development in Johannesburg [99] and the Rio +20 Earth Summit [100]. The following criteria were used when selecting indicators for individual thematic areas:

- The existence of a substantive relationship (whether the indicator reflects economic development and the idea of sustainable development);

- International comparability;

- Data availability;

- Data source credibility.

Since the validity of weighing indicators relating to spatial data has been questioned by several authors, the assignment of weight coefficients to partial indicators was abandoned. This solution is supported, among others, by the fact that the indicators that were not selected would be given zero weights by default [101,102].

Stage 2: Evaluating the discriminant ability of partial indicators and their capacity the degree of correlation with other indicators. The research eliminated those indicators for which the value of the coefficient of variation was lower than the arbitrarily set critical threshold value of this coefficient $\left(\mathrm{r}^{*}=15 \%\right)$ were eliminated. Therefore, the following indicators were excluded from the research: X20, X21, and X23. Then, for each subject area, an analysis of the Persona correlation matrix was performed. From each thematic area, one of the indicators for which the correlation coefficient exceeded the threshold value of $\mathrm{r}^{*}=0.7$ was eliminated (two highly correlated indicators provide similar information, therefore it is justified to eliminate one of them). In this way, from the set of indicators describing the indicated thematic areas of economic development, the following indicators were eliminated: $\mathrm{X} 2, \mathrm{X} 12$, and X13.

Stage 3: Determining the nature of the indicators according to the way they affect economic development, i.e., the division of indicators into stimulants, destimulants, and nominants [89,103]. On the basis of the substantive analysis, the nature of the indicators was determined, including stimulants $(X 1, X 3, X 5, X 6, X 7, X 9, X 10, X 11, X 14, X 15, X 16, X 18$, $X 19, X 20, X 25, X 26)$ and destimulants (X4, X18, X24, X25, X28). None of the indicators were nominative. The destimulants were converted into stimulants:

$$
x_{i j}^{S}=-x_{i j}^{D}
$$

where:

$x_{i j}^{S}$ - value of the $j$-th destimulant variable in the $i$-th object (EU country) converted into a stimulant;

$x_{i j}^{D}$-value of the $j$-th destimulant variable in the $i$-th object (EU country). 
Table 1. Partial indicators (source: own study based on Eurostat data).

\begin{tabular}{|c|c|c|}
\hline Symbol & Variable & Unit of Measure \\
\hline \multicolumn{3}{|c|}{ Area 1-Economy } \\
\hline $\mathrm{X} 1$ & Real GDP per capita growth & Percentage change on previous year \\
\hline $\mathrm{X} 2$ & Real GDP growth & Percentage change on previous year \\
\hline $\mathrm{X} 3$ & Investment rate & Percentage of gross domestic product (GDP) \\
\hline X4 & General government debt & Percentage of gross domestic product (GDP) \\
\hline $\mathrm{X} 5$ & Environmental tax revenues & Percentage of gross domestic product (GDP) \\
\hline \multicolumn{3}{|c|}{ Area 2-Production and transportation patterns } \\
\hline $\mathrm{X} 6$ & Circular material use rate & Percentage of material input for domestic use \\
\hline $\mathrm{X} 7$ & $\begin{array}{l}\text { Resource productivity and domestic } \\
\text { material consumption (DMC) }\end{array}$ & Purchasing power standard (PPS) per kilogram \\
\hline $\mathrm{X} 8$ & Area under organic farming & Percentage of total utilized agricultural area \\
\hline X9 & $\begin{array}{c}\text { Share of rail and inland waterways in total } \\
\text { freight transport }\end{array}$ & Percentage \\
\hline $\mathrm{X} 10$ & $\begin{array}{c}\text { Share of collective transport modes in total } \\
\text { passenger transport }\end{array}$ & Percentage of total inland passenger-km \\
\hline $\mathrm{X} 11$ & Volume of freight transport relative to GDP & Index, $2010=100$ \\
\hline \multicolumn{3}{|c|}{ Area 3-Innovation } \\
\hline $\mathrm{X} 12$ & $\begin{array}{l}\text { Human resources in science and technology } \\
\text { (HRST) }\end{array}$ & Percentage of active population \\
\hline $\mathrm{X} 13$ & R\&D personnel & $\begin{array}{l}\text { Percentage of active population-numerator in } \\
\text { full-time equivalent (FTE). }\end{array}$ \\
\hline X14 & Gross domestic expenditure on $R \& D$ & Percentage of gross domestic product (GDP) \\
\hline X15 & $\begin{array}{l}\text { Government support to agricultural research } \\
\text { and development }\end{array}$ & Euro per inhabitant \\
\hline $\mathrm{X} 16$ & $\begin{array}{c}\text { Patent applications to the European Patent } \\
\text { Office }\end{array}$ & Per million inhabitants \\
\hline \multicolumn{3}{|c|}{ Area 4-Energy patterns } \\
\hline $\mathrm{X} 17$ & Energy productivity & $\begin{array}{c}\text { Purchasing power standard (PPS) per kilogram of } \\
\text { oil equivalent }\end{array}$ \\
\hline $\mathrm{X} 18$ & Primary energy consumption & Tons of oil equivalent (TOE) per capita \\
\hline X19 & $\begin{array}{l}\text { Share of renewable energy in gross final } \\
\text { energy consumption }\end{array}$ & Percentage of the gross final energy consumption \\
\hline $\mathrm{X} 20$ & $\begin{array}{l}\text { Greenhouse gas emissions intensity of } \\
\text { energy consumption }\end{array}$ & Index, $2000=100$ \\
\hline $\mathrm{X} 21$ & $\begin{array}{l}\text { Average } \mathrm{CO}_{2} \text { emissions per km from new } \\
\text { passenger cars }\end{array}$ & $\mathrm{g} \mathrm{CO}_{2}$ per $\mathrm{km}$ \\
\hline $\mathrm{X} 22$ & Renewable energy sources in transport & Percentage \\
\hline \multicolumn{3}{|c|}{ Area 5-Employment } \\
\hline $\mathrm{X} 23$ & Employment rate & Percentage of population aged 20 to 64 \\
\hline $\mathrm{X} 24$ & $\begin{array}{l}\text { Young people neither in employment nor in } \\
\text { education and training }\end{array}$ & Percentage of population aged 15 to 29 \\
\hline $\mathrm{X} 25$ & Labor cost index & Percentage change on previous period \\
\hline $\mathrm{X} 26$ & Nominal labor productivity per person & Percentage of EU27 total, current prices \\
\hline $\mathrm{X} 27$ & Overall employment growth & $\begin{array}{c}\text { The percentage change on previous period (based } \\
\text { on persons) }\end{array}$ \\
\hline $\mathrm{X} 28$ & Unemployment rate & Percentage of active population \\
\hline
\end{tabular}

Stage 4: Normalization of indicators. Two methods of normalization of indicators were used: standardization (Hellwig's method) and zero unitization (TOPSIS method) [104]:

- Standardization:

$$
z_{i j}=\frac{x_{i j}-\bar{x}_{j}}{S_{j}}
$$

where:

$z_{i j}$-normalized values of the $j$-th variable in the i-th object (EU country);

$x_{i j}$-value of the $j$-th variable in the $i$-th object (EU country);

$S_{j}$-standard deviation. 
- Zero unitization:

$$
z_{i j}=\frac{x_{i j}-\min _{i} x_{i j}}{\max _{i} x_{i j}-\min _{i} x_{i j}}
$$

where:

$\min _{i} x_{i j}$-minimum of the $j$-th variable;

$\max _{i} x_{i j}$-maximum of the $j$-th variable.

Stage 5: Calculation of the taxonomic measures and preparation of rankings of EU countries. For the respective methods, this stage was as follows:

- Hellwig's method

1. The coordinates of the pattern and the distances of individual EU countries from the pattern were determined (for the stimulant indicators):

Pattern coordinates:

$$
z_{0 j}=\max _{i}\left\{z_{i j}\right\}
$$

Distance of objects from the pattern:

$$
d_{i 0}=\sqrt{\frac{1}{n} \sum_{i=1}^{m}\left(z_{i j}-z_{0 j}\right)^{2}}
$$

2. The values of the synthetic variable were determined:

$$
\begin{gathered}
s_{i}=1-\frac{d_{i 0}}{d_{0}} \\
d_{0}=\bar{d}_{0}+2 s_{d} \\
\bar{d}=\frac{1}{n} \sum_{i=1}^{n} d_{i 0} \\
S_{d}=\sqrt{\frac{1}{n} \sum_{i=1}^{n}\left(d_{i 0}-\bar{d}_{0}\right)^{2}}
\end{gathered}
$$

where:

in general $s_{i} \in[0 ; 1]$; $\max _{\mathrm{i}}\left\{\mathrm{s}_{\mathrm{i}}\right\}$ - best item; $\min _{\mathrm{i}}\left\{\mathrm{s}_{\mathrm{i}}\right\}-$ worst item.

- $\quad$ TOPSIS method

1. The coordinates of the pattern and the anti-pattern as well as the distances of the objects (EU countries) from the pattern and anti-pattern (for the stimulants indicators) were determined:

Pattern coordinates:

$$
\mathrm{z}_{0 \mathrm{j}}^{+}=\max _{\mathrm{i}}\left\{z_{i j}\right\}
$$

Anti-pattern coordinates:

$$
z_{0 j}^{-}=\min _{i}\left\{z_{i j}\right\}
$$

Distance of objects from the pattern:

$$
d_{i 0}^{+}=\sqrt{\sum_{j=1}^{m}\left(z_{i j}-z_{0 j}^{+}\right) 2}
$$


Distance of objects from the anti-pattern:

$$
d_{i 0}^{-}=\sqrt{\sum_{j=1}^{m}\left(z_{i j}-z_{0 j}^{-}\right) 2}
$$

2. The values of the synthetic variable were determined:

$$
s_{i}=\frac{d_{i 0}^{-}}{d_{i 0}^{+}+d_{i 0}^{-}}
$$

where:

in general $s_{i} \in[0 ; 1]$;

$\max _{\mathrm{i}}\left\{\mathrm{s}_{\mathrm{i}}\right\}$ - best item;

$\min _{i}\left\{s_{i}\right\}-$ worst item.

In order to test the convergence of the results obtained using the two methods, the value of Spearman's rank correlation coefficients between taxonomic measures was calculated. In addition, the presented study also grouped EU countries. By using the so-called threshold method [40], four clusters of countries were distinguished:

Cluster 1 (countries with a very high level of development):

$$
s_{i} \geq \overline{s_{i}}+S_{s_{i}}
$$

Cluster 2 (countries with a high level of development):

$$
\overline{s_{i}}+S_{s_{i}}>s_{i} \geq \overline{s_{i}}
$$

Cluster 3 (countries with an average level of development):

$$
\overline{s_{i}}>s_{i} \geq \overline{s_{i}}-S_{s_{i}}
$$

Cluster 4 (countries with a low level of development):

$$
s_{i}<\overline{s_{i}}-S_{s_{i}}
$$

where:

$s_{i}$ - synthetic variable;

$\overline{s_{i}}$ - arithmetic mean of the synthetic variable;

$S_{s_{i}}$-standard deviation of the synthetic variable.

\section{Research Results and Discussion}

The research shows that in the EU, there is a different level of economic development in relation to the concept of sustainable development. In 2014, the average value of the synthetic measure calculated according to Hellwig's method was 0.1560 . The highest level of this measure was noted in Austria (0.2885) and Sweden (0.2842) and Denmark (0.2824), and the lowest in Greece (-0.0319), Bulgaria (0.0185), and Cyprus (0.0286). The value of the synthetic measure for the countries with the highest values was therefore several times higher than the measure for the countries with the lowest values. A similar situation also took place in 2019. The significant diversification of the economic development of EU countries is also confirmed by the high coefficient of variation, calculated by the Hellwig method in both 2014 and 2019, which amounted to over $51 \%$.

The differences in the level of economic development in the EU are also indicated by the TOPSIS method, although the differences in the level of the synthetic measure between individual countries are not as large as in the case of the Hellwig method.

From the research conducted, it is also evident that in the EU in 2019, compared to 2014, the average value of the synthetic measure decreased (by approximately 5\%), as well 
as the maximum and minimum value. A lot of EU countries recorded a decline in the synthetic measure, which indicates unfavorable changes in their economic development in relation to sustainable development. In the case of the Hellwig method, a decrease in the synthetic measure was recorded by as many as 16 countries (increase in 11 countries), while in the case of the TOPSIS method, a decrease was recorded in 17 countries (an increase in 9 countries) (Table 2$)$.

Table 2. The taxonomic measures.

\begin{tabular}{|c|c|c|c|c|}
\hline \multirow{2}{*}{ EU Countries } & \multicolumn{2}{|c|}{ The Hellwig Method } & \multicolumn{2}{|c|}{ The TOPSIS Method } \\
\hline & 2014 & 2019 & 2014 & 2019 \\
\hline Austria & 0.2885 & 0.2597 & 0.5250 & 0.5080 \\
\hline Belgium & 0.1932 & 0.1870 & 0.4483 & 0.4576 \\
\hline Bulgaria & 0.0185 & 0.0325 & 0.3527 & 0.3897 \\
\hline Croatia & 0.1037 & 0.1385 & 0.3898 & 0.4274 \\
\hline Cyprus & 0.0286 & 0.0881 & 0.3740 & 0.3632 \\
\hline Czechia & 0.1703 & 0.1394 & 0.4503 & 0.4287 \\
\hline Denmark & 0.2824 & 0.2841 & 0.5283 & 0.5273 \\
\hline Estonia & 0.1564 & 0.2226 & 0.4707 & 0.5063 \\
\hline Finland & 0.2259 & 0.2185 & 0.5035 & 0.4726 \\
\hline France & 0.2059 & 0.1776 & 0.4443 & 0.4238 \\
\hline Germany & 0.2224 & 0.1940 & 0.4728 & 0.4600 \\
\hline Greece & -0.0319 & -0.0204 & 0.3401 & 0.3592 \\
\hline Hungary & 0.1907 & 0.1266 & 0.4547 & 0.4244 \\
\hline Ireland & 0.2166 & 0.2658 & 0.4880 & 0.5113 \\
\hline Italy & 0.1809 & 0.1305 & 0.4505 & 0.4205 \\
\hline Latvia & 0.1397 & 0.1540 & 0.4476 & 0.4517 \\
\hline Lithuania & 0.1191 & 0.0776 & 0.4183 & 0.4178 \\
\hline Luxembourg & 0.1464 & 0.1392 & 0.4759 & 0.4513 \\
\hline Malta & 0.1122 & 0.1236 & 0.4257 & 0.4481 \\
\hline Netherlands & 0.2297 & 0.2458 & 0.5081 & 0.5240 \\
\hline Poland & 0.1477 & 0.0747 & 0.4056 & 0.4043 \\
\hline Portugal & 0.0629 & 0.0895 & 0.3746 & 0.3965 \\
\hline Romania & 0.1179 & 0.0742 & 0.4264 & 0.4058 \\
\hline Slovakia & 0.1444 & 0.1028 & 0.3961 & 0.3852 \\
\hline Slovenia & 0.1552 & 0.1484 & 0.4389 & 0.4326 \\
\hline Spain & 0.1018 & 0.1004 & 0.3776 & 0.3700 \\
\hline Sweden & 0.2842 & 0.2476 & 0.5289 & 0.5145 \\
\hline MIN & -0.0319 & -0.0204 & 0.3401 & 0.3592 \\
\hline MAX & 0.2885 & 0.2841 & 0.5289 & 0.5273 \\
\hline Average & 0.1560 & 0.1490 & 0.4414 & 0.4401 \\
\hline $\begin{array}{l}\text { Standard } \\
\text { deviation }\end{array}$ & 0.0795 & 0.0759 & 0.0535 & 0.0501 \\
\hline
\end{tabular}

On the basis of the values of taxonomic measures, rankings of the EU countries were created according to the level of economic development in relation to sustainable development. In the case of both methods, the highest positions, both in 2014 and 2019, were held by Austria, Sweden, Denmark, and the Netherlands, which for many years were characterized by the highest level of economic development in relation to sustainable development in the EU. On the other hand, the lowest positions in the ranking of EU countries were occupied by Greece, Bulgaria, and Cyprus. Such low positions of these countries are a consequence of low or very low values of the partial indicators considered (Table 3). 
Table 3. Ranking of EU countries.

\begin{tabular}{ccccccc}
\hline \multirow{2}{*}{ EU Countries } & \multicolumn{3}{c}{ The Hellwig Method } & \multicolumn{3}{c}{ The TOPSIS Method } \\
\cline { 2 - 7 } & $\mathbf{2 0 1 4}$ & $\mathbf{2 0 1 9}$ & Rank Change & $\mathbf{2 0 1 4}$ & $\mathbf{2 0 1 9}$ & Rank Change \\
\hline Austria & 1 & 3 & -2 & 3 & 5 & -2 \\
Belgium & 9 & 9 & 0 & 13 & 9 & +4 \\
Bulgaria & 26 & 26 & 0 & 26 & 23 & +3 \\
Croatia & 22 & 15 & +7 & 22 & 15 & +7 \\
Cyprus & 25 & 22 & +3 & 25 & 26 & -1 \\
Czechia & 12 & 13 & -1 & 12 & 14 & -2 \\
Denmark & 3 & 1 & +2 & 2 & 1 & +1 \\
Estonia & 13 & 6 & +7 & 9 & 6 & +3 \\
Finland & 5 & 7 & -2 & 5 & 7 & -2 \\
France & 8 & 10 & -2 & 15 & 17 & -2 \\
Germany & 6 & 8 & -2 & 8 & 8 & 0 \\
Greece & 27 & 27 & 0 & 27 & 27 & 0 \\
Hungary & 10 & 17 & -7 & 10 & 16 & -6 \\
Ireland & 7 & 2 & +5 & 6 & 4 & +2 \\
Italy & 11 & 16 & -5 & 11 & 18 & -7 \\
Latvia & 18 & 11 & +7 & 14 & 10 & +4 \\
Lithuania & 19 & 23 & -4 & 19 & 19 & 0 \\
Luxembourg & 16 & 14 & +2 & 7 & 11 & -4 \\
Malta & 21 & 18 & +3 & 18 & 12 & +6 \\
Netherlands & 4 & 5 & -1 & 4 & 2 & +2 \\
Poland & 15 & 24 & -9 & 20 & 21 & -1 \\
Portugal & 24 & 21 & +3 & 24 & 22 & +2 \\
Romania & 20 & 25 & -5 & 17 & 20 & -3 \\
Slovakia & 17 & 19 & -2 & 21 & 24 & -3 \\
Slovenia & 14 & 12 & +2 & 16 & 13 & +3 \\
Spain & 23 & 20 & +3 & 23 & 25 & -2 \\
Sweden & 2 & 4 & -2 & 1 & 3 & -2 \\
\hline
\end{tabular}

In the respective years, no significant differences were observed between the positions of individual countries in the rankings obtained based on the methods of ordering applied. The vast majority of countries were ranked similarly in both methods used. However, the greatest doubts are raised by the results obtained for the following countries: France (the difference between the rankings is seven positions), Luxembourg (in 2014, the difference between the rankings was nine positions; in 2019, compared to 2014, the position improved according to the Hellwig method, and the position deteriorated according to the TOPSIS method), and Poland (in 2019, compared to 2014, according to the Hellwig method, the position deteriorated by nine positions, and according to the TOPSIS method, the position deteriorated by one position). Moreover, in the case of Cyprus and Spain, according to the Hellwig method, the position of countries improved, and according to the TOPSIS method, it deteriorated (Table 3). Therefore, in order to test the convergence of the results obtained with the TOPSIS method and Hellwig method, the values of Spearman's rank correlation coefficients between them were appointed. Despite the doubts indicated above, in the analyzed years, the ratios were very high and amounted to 0.9231 (2014) and 0.9249 (2019), respectively. The critical value rank correlation coefficient of the Spearman (significance level of $\alpha=0.05$ and for 27 observations) amounts to 0.3827 , hence it can be appointed that there is a statistically significant convergence setting in the order of the EU countries between the individual comparisons.

Another analyzed issue was the clustering of EU countries in terms of a similar level of economic development in the relation of the implementation of the concept of sustainable development. The clustering was performed on the basis of the results obtained with the Hellwig's method (Table 3) and TOPSIS method (Table 4). According to the threshold method, the EU countries were divided into four clusters: cluster 1, countries with a very high level of development; cluster 2, countries with a high level of development; cluster 3, 
countries with an average level of development; and cluster 4, countries with a low level of development.

Table 4. Classification of EU countries into clusters: Hellwig's method.

\begin{tabular}{|c|c|c|c|}
\hline Cluster & Level of Development & Clustering Rule & EU Countries \\
\hline \multicolumn{4}{|c|}{2014} \\
\hline I & very high & $\mathrm{zi} \geq 0.2356$ & Austria, Denmark, Sweden \\
\hline II & high & $0.2356>\mathrm{zi} \geq 0.1560$ & $\begin{array}{l}\text { Belgium, Czechia, Estonia, Finland, } \\
\text { France, Germany, Hungary, Ireland, } \\
\text { Italy, Netherlands }\end{array}$ \\
\hline III & medium & $0.1560>\mathrm{zi} \geq 0.0765$ & $\begin{array}{c}\text { Croatia, Latvia, Lithuania, Luxembourg, } \\
\text { Malta, Poland, Romania, Slovakia, } \\
\text { Slovenia, Spain }\end{array}$ \\
\hline IV & low & $\mathrm{zi}<0.0765$ & Bulgaria, Cyprus, Greece, Portugal \\
\hline \multicolumn{4}{|c|}{2019} \\
\hline I & very high & $\mathrm{zi} \geq 0.2249$ & $\begin{array}{c}\text { Austria, Denmark, Ireland, } \\
\text { Netherlands, Sweden }\end{array}$ \\
\hline II & high & $0.2240>\mathrm{zi} \geq 0.1490$ & $\begin{array}{c}\text { Belgium, Estonia, Finland, France, } \\
\text { Germany, Latvia }\end{array}$ \\
\hline III & medium & $0.1490>\mathrm{zi} \geq 0.0731$ & $\begin{array}{c}\text { Croatia, Cyprus, Czechia, Hungary, Italy, } \\
\text { Lithuania, Luxembourg, Malta, Poland, } \\
\text { Portugal, Romania, Slovakia, } \\
\text { Slovenia, Spain }\end{array}$ \\
\hline IV & low & $\mathrm{zi}<0.0731$ & Bulgaria, Greece \\
\hline
\end{tabular}

In the analyzed years $(2014,2019)$, the clustering results were very similar in both methods used. In relatively few cases, the countries took a different cluster, and it was a difference by one cluster only, i.e., for example, according to the Hellwig method, the country was in cluster I and according to the TOPSIS method in cluster II. There was no case where the difference in the position of the country was two or three clusters, i.e., for example, according to the Hellwig method, the country was in cluster II, and according to the TOPSIS method in cluster IV (Tables 3 and 4). In only a few cases, countries took a different cluster, and this was a difference of only one cluster.

In 2014, according to the Hellwig method, the most numerous clusters were the countries characterized by a high (10 EU countries) and an average level of development (10 EU countries), while the least numerous was the cluster characterized by a very high development (three EU countries). In 2019, however, there was a change, as the most numerous cluster included only countries with an average level of development (14 EU countries), while the least numerous countries belonged to the cluster with a low level of development (two countries) (Table 4, Figure 1).
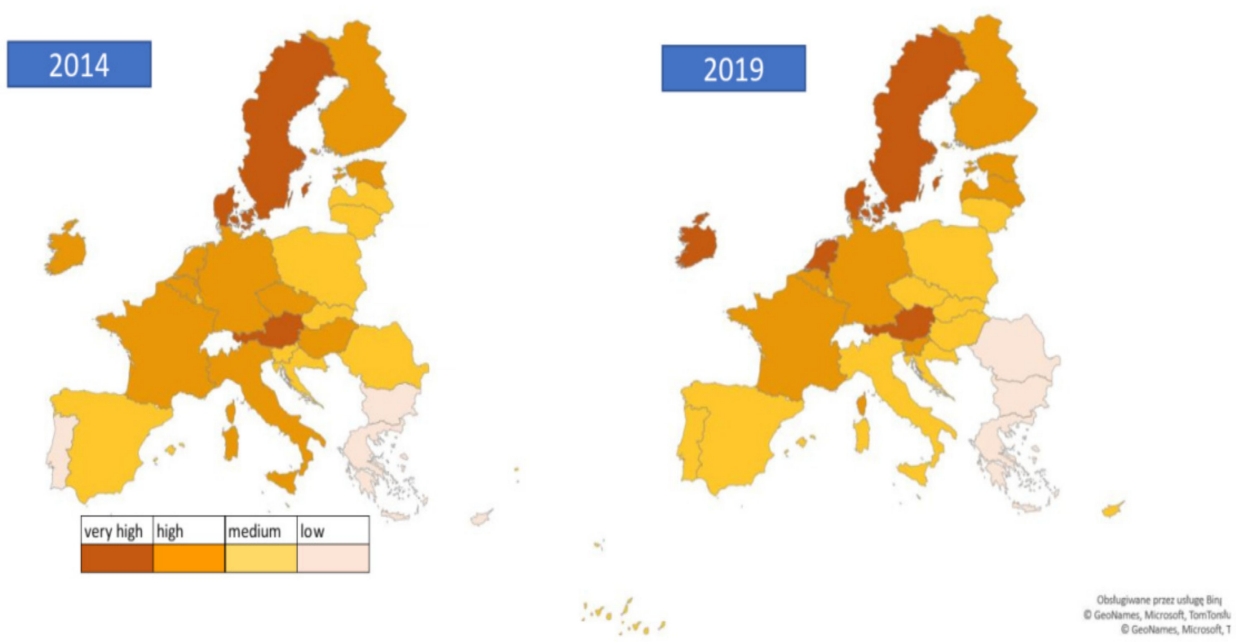

Figure 1. Classification of EU countries into clusters: Hellwig's method. 
In 2014, according to the TOPSIS method, the most numerous clusters were the countries characterized by a high level of development (10 EU countries), while the least numerous was the cluster characterized by very high (five EU countries) and low development (five EU countries). In 2019, however, there was a change, as the most numerous cluster included countries with an average level of development (10 EU countries), while the least numerous countries belonged to the cluster with a low level of development (five countries) (Table 5, Figure 2).

Table 5. Classification of EU countries into clusters: TOPSIS method.

\begin{tabular}{|c|c|c|c|}
\hline Cluster & $\begin{array}{c}\text { Level of } \\
\text { Development }\end{array}$ & Clustering Rule & EU Countries \\
\hline \multicolumn{4}{|c|}{2014} \\
\hline $\mathrm{I}$ & very high & $\mathrm{zi} \geq 0.4948$ & $\begin{array}{l}\text { Austria, Denmark, Finland, } \\
\text { Netherlands, Sweden }\end{array}$ \\
\hline II & high & $0.4948>\mathrm{zi} \geq 0.4414$ & $\begin{array}{l}\text { Belgium, Czechia, Estonia, France, } \\
\text { Germany, Hungary, Ireland, Italy, } \\
\text { Latvia, Luxembourg }\end{array}$ \\
\hline III & medium & $0.4414>\mathrm{zi} \geq 0.3879$ & $\begin{array}{l}\text { Croatia, Lithuania, Malta, Poland, } \\
\text { Romania, Slovakia, Slovenia }\end{array}$ \\
\hline IV & low & $\mathrm{zi}<0.3879$ & $\begin{array}{c}\text { Bulgaria, Cyprus, Greece, } \\
\text { Portugal, Spain }\end{array}$ \\
\hline \multicolumn{4}{|c|}{2019} \\
\hline I & very high & $\mathrm{zi} \geq 0.4902$ & $\begin{array}{c}\text { Austria, Denmark, Estonia, Ireland, } \\
\text { Netherlands, Sweden }\end{array}$ \\
\hline II & high & $0.4902>\mathrm{zi} \geq 0.4401$ & $\begin{array}{c}\text { Belgium, Finland, Germany, Latvia, } \\
\text { Luxembourg, Malta }\end{array}$ \\
\hline III & medium & $0.4401>\mathrm{zi} \geq 0.3899$ & $\begin{array}{c}\text { Croatia, Czechia, France, Hungary, } \\
\text { Italy, Lithuania, Poland, Portugal, } \\
\text { Romania, Slovenia }\end{array}$ \\
\hline IV & low & $\mathrm{zi}<0.3899$ & $\begin{array}{c}\text { Bulgaria, Cyprus, Greece, } \\
\text { Slovakia, Spain }\end{array}$ \\
\hline
\end{tabular}
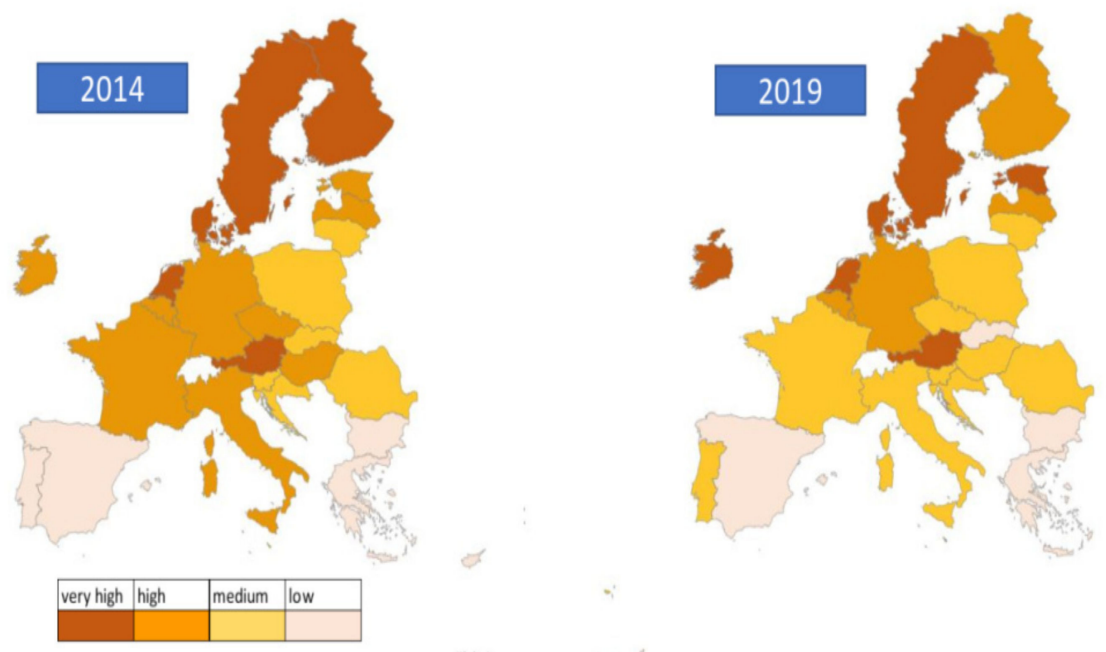

Figure 2. Classification of EU countries into clusters: TOPSIS method.

According to the Hellwig method and the TOPSIS method, the following countries: Austria, Denmark, and Sweden, are characterized by a stable very high level of development in both methods used (they belonged to cluster 1 in both 2014 and 2019). In addition, Portugal should be assessed positively, as in 2019, they were in the cluster characterized by a higher level of development compared to 2014. On the other hand, unfavorable changes 
in the level of development were noted by the following countries: the Czech Republic, Hungary, and Italy, which in 2019 were in clusters with a lower level of development compared to 2014 (Tables 4 and 5).

\section{Conclusions}

The study was done in two variants. The first study concerned the evaluation of the diversity of EU countries states in conditions of economic development in relation to the implementation of the sustainable development idea in two years: 2014 and 2019. The indicators describing the individual areas provide an overview of the EU's progress towards sustainable development in terms of economic goals, taking into account energy concerns. The second study adopted the temporal approaches. It evaluated the progress of the EU countries towards economic development in relation to sustainable development in 2019 compared to 2014. The results of the analyses carried out may contribute to the assessment of the effects of the development policy pursued in the EU members so far. On the basis of the presented results, a conclusion can be drawn that positive changes are taking place in many UE countries, bringing them closer to the successful implementation of the paradigm of sustainable development, one of the main priorities of the Europe 2020 Strategy [60].

The article sets out taxonomic measures of economic development in view of the implementation of the sustainable concept by means of the two taxonomic methods on the basis of which the studied countries were ranked. Moreover, as a result of the conducted research, four clusters of countries were created, which are characterized by a similar level of economic development. The conducted analysis proves that in the analyzed years, the countries with the highest level of development were Austria, Sweden, Denmark, and the Netherlands. The following countries received very low ranks: Greece, Bulgaria, and Cyprus.

The conducted research revealed significant disproportions between the respective EU countries in terms of the level of economic development in relation to implementing the concept of sustainable development. It seems justified to take action aimed at eliminating the differences between the countries in the analyzed aspect. It is necessary to both intensify efforts at the level of individual Member States and the EU, oriented towards pro-development activities. It should be mentioned here that the analysis of the research results indicates some negative phenomena, possibly indicating some unfavorable changes in many EU countries:

- In 2019, compared to 2014, the average value of the synthetic measure in the EU decreased (by approximately $5 \%$ ), as well as the maximum and minimum value; 16 countries saw a decline in the synthetic measure;

- The clustering obtained with the threshold method shows that in 2014, the cluster of countries with a high (Hellwig method, TOPSIS method) and an average level of development (Hellwig method) dominated, while in 2019, the cluster with an average level of development was already dominant.

Research shows that the energy-related situation of individual countries significantly determines economic development, which is clearly differentiated across the EU. The diversity of the energy sector in the EU is the result of both endogenous and exogenous factors. Let us note that the structures of energy production, and thus the energy security of individual countries, are often conditioned by historical considerations, such as the adopted solutions in the field of energy production, as well as practical ones, resulting from the availability of the raw material. In the EU, there are countries with economies that are heavily dependent on fossil fuels (most EU members) but also those with an increasing share of renewable energy sources. The surveyed countries also differ in their approach regarding the shaping of relations with energy-supplying states, especially the Russian Federation. The improvement of the current state of affairs has been adversely affected by the collision of environmental and energy goals. The EU is striving to lead the prime in environmental protection, which means high costs for sector transformation and this may 
result in deterioration of the competitive position of both individual Member States and the entire community. The EU is an economy largely propelled by fossil fuels, to which it does not have sufficient access to cover its current and future needs. The dependence of the European economy on fossil fuels means there is a need to look for new suppliers among third countries, which may trigger a strong dependence on new suppliers and therefore a significant impact on economic development. It also means that the achievement of the EU's economic goals depends heavily on the global economic conditions for energy resources and their tariffs. In accordance with the assumptions laid out in the strategic documents, the EU aims to introduce high standards of environmental protection, but its expectations collide with those of the United States, Russia, China, Brazil, and India, which are all major pollutants. While the EU strives for sustainable development, the other countries think about effective economic development and are reluctant to introduce any restrictions that could disrupt their national policies, thus making it necessary to seek an environmental compromise on the international forum [105].

The conducted research is not free from limitations that may affect the obtained results and conclusions drawn. Let us stress that the main barrier for the conducted research was issues related to access to the necessary data.

The research and results obtained as part of this study may constitute material for further analyses using other statistical methods and other partial indicators. They encourage the implementation of similar research at the level of other countries.

Author Contributions: Conceptualization, J.J.-G., J.W. and A.B.; methodology, J.J.-G., J.W. and A.B.; software, J.J.-G., J.W. and A.B.; validation, J.J.-G., J.W. and A.B.; formal analysis, J.J.-G., J.W. and A.B.; investigation, J.J.-G., J.W. and A.B.; resources, J.J.-G., J.W. and A.B.; data curation, J.J.-G., J.W. and A.B.; writing-original draft preparation, J.J.-G., J.W. and A.B.; writing-review and editing, J.J.-G., J.W. and A.B.; visualization, J.J.-G., J.W. and A.B.; supervision, J.J.-G., J.W. and A.B.; project administration, J.J.-G., J.W. and A.B. All authors have read and agreed to the published version of the manuscript.

Funding: This research was funded by the Institute of Economics and Finance-University of Zielona Góra.

Institutional Review Board Statement: Not applicable.

Informed Consent Statement: Not applicable.

Data Availability Statement: Database used is open access Eurostat.

Conflicts of Interest: The authors declare no conflict of interest.

\section{References}

1. Teodorescu, A.M. From Economic Development to Sustainable Economic Development. An. Ser. Ştiinţe Econ. Timişs. 2015, 21, 404-408.

2. Butlin, J. Our common future. By World commission on environment and development. (London, Oxford University Press, 1987). J. Int. Dev. 1989, 1, 284-287. [CrossRef]

3. Wójtowicz, A. Polityka Energetyczna Jako Narzędzie Realizacji Koncepcji Zrównoważonego Rozwoju Energetyki Polski Po 2004 Roku; Oficyna Wydawnicza SGH: Warszawa, Poland, 2021.

4. Rogall, H. Ekonomia Zrównoważonego Rozwoju. Teoria i Praktyka; Zysk i S-Ka: Poznań, Poland, 2010.

5. Dabbous, A.; Tarhini, A. Does sharing economy promote sustainable economic development and energy efficiency? Evidence from OECD countries. J. Innov. Knowl. 2021, 6, 58-68. [CrossRef]

6. Krkošková, R. Causality between Energy Consumption and Economic Growth in the V4 Countries. Technol. Econ. Dev. Econ. 2021, 27, 900-920. [CrossRef]

7. Sharma, G.D.; Tiwari, A.K.; Erkut, B.; Mundi, H.S. Exploring the nexus between non-renewable and renewable energy consumptions and economic development: Evidence from panel estimations. Renew. Sustain. Energy Rev. 2021, 146, 111152. [CrossRef]

8. Wang, J.; Zhang, S.; Zhang, Q. The relationship of renewable energy consumption to financial development and economic growth in China. Renew. Energy 2021, 170, 897-904. [CrossRef]

9. Carley, S.; Lawrence, S. Energy-Based Economic Development: How Clean Energy Can Drive Development and Stimulate Economic Growth; Springer: London, UK, 2014. 
10. Yusuf, J.-E.; Neill, K.A. State Energy-Based Economic Development Policies and Examples. Econ. Dev. Q. 2013, 27, 240-249. [CrossRef]

11. Carley, S.; Brown, A.; Lawrence, S. Economic Development and Energy: From Fad to a Sustainable Discipline? Econ. Dev. Q. 2012, 26, 111-123. [CrossRef]

12. Carley, S.; Lawrence, S.; Brown, A.; Nourafshan, A.; Benami, E. Energy-based economic development. Renew. Sustain. Energy Rev. 2011, 15, 282-295. [CrossRef]

13. Xundi, D.; Liyin, S.; Saixing, Z.; Jose Jorge, O.; Xiaoling, Z. Relationship between energy consumption and economic development in construction industry. J. Eng. Des. Technol. 2010, 8, 257-273. [CrossRef]

14. Sokół, H. Zrównoważona energetyka w ramach koncepcji zrównoważonego rozwoju. In Ekonomiczne Dylematy Zrównoważonego Rozwoju. Działalność—Restrukturyzacja-Finansowanie-Upadłość; Dec, P., Ed.; Oficyna Wydawnicza SGH: Warszawa, Poland, 2020; pp. 133-156.

15. Fortuński, B. Polityka energetyczna Unii Europejskiej-3 3 20. Diagnoza i perspektywy w kontekście zrównoważonego rozwoju. Pr. Nauk. Uniw. Ekon. Wroctawiu 2016, 453, 179-189.

16. Czech, A. Analiza wybranych wskaźników bezpieczeństwa energetycznego Polski w kontekście zrównoważonego rozwoju. Studia Pr. WNEiZ Uniw. Szczeciński 2018, 53, 23-35.

17. Wojtkowska-Łodej, G. W kierunku budowania gospodarki niskoemisyjnej w Unii Europejskiej-Działania w obszarze energii i klimatu. Pr. Nauk. Uniw. Ekon. Wrocławiu 2016, 453, 300-311.

18. European Union. Statement by Commissioner Gentiloni on the 2021 report on Sustainable Development in the European Union. Brussels, Belgium, 2021. Available online: https://ec.europa.eu/commission/presscorner/detail/en/STATEMENT_21_3006 (accessed on 11 July 2021).

19. Pasko, O.; Balla, I.; Levytska, I.; Semenyshena, N. Accountability on Sustainability in Central and Eastern Europe: An Empirical Assessment of Sustainability-Related Assurance. Comp. Econ. Res. 2021, 24, 27-52.

20. Rajnoha, R.; Lesníková, P.; Vahančík, J. Sustainable economic development: The relation between economic growth and quality of life in V4 and Austria. Econ. Sociol. 2021, 14, 341-357. [CrossRef]

21. Szymańska, A. Reducing Socioeconomic Inequalities in the European Union in the Context of the 2030 Agenda for Sustainable Development. Sustainability 2021, 13, 7409. [CrossRef]

22. Chłą, M. Elements of Sustainable Development in Selected European Union Countries. Ekon. Prawo 2020, 19, 435-447. [CrossRef]

23. Kiselakova, D.; Stec, M.; Grzebyk, M.; Sofrankova, B. A Multidimensional Evaluation of the Sustainable Development of European Union Countries-An Empirical Study. J. Compet. 2020, 12, 56-73.

24. Sompolska-Rzechuła, A. Selection of the Method of Linear Ordering Using the Example of Assessing the Level of Socio-economic Development of European Union countries. Pr. Nauk. Uniw. Ekon. Wrocławiu 2020, 7, 118-129. [CrossRef]

25. Ergül Halisçelik, E.; Soytas, M.A. Sustainable development from millennium 2015 to Sustainable Development Goals 2030. Sustain. Dev. 2019, 27, 545-572. [CrossRef]

26. European Union. European Union presents its progress towards sustainable development. Brussels, Belgium, 2019. Available online: https:/ / ec.europa.eu/commission/presscorner/detail/en/IP_19_4250 (accessed on 8 August 2021).

27. Vié, A.; Colapinto, C.; Torre, D.L.; Liuzzi, D. The long-run sustainability of the European Union countries: Assessing the Europe 2020 strategy through a fuzzy goal programming model. Manag. Decis. 2019, 57, 523-542. [CrossRef]

28. Bakk, I.; Cheba, K. An Analysis of Dynamic Changes in Selected Areas of Sustainable Development of the European Union Countries. Folia Oecon. Stetin. 2018, 18, 93-107. [CrossRef]

29. Kozien, E. Elements of Concept Of Sustainable Development Realised Through Project; Varazdin Development and Entrepreneurship Agency (VADEA): Varazdin, Croatia, 2021.

30. Kozien, E.; Kozien, A. The Sustainability Development Concept Under the Regulatons in Force of The Treaty on European Union and the Treaty on The Functioning of The European Union-Legal And Economical View; Varazdin Development and Entrepreneurship Agency (VADEA): Varazdin, Croatia, 2018.

31. Czaja, S.; Becla, A. Wybrane informacyjne problemy definiowania zrównoważonego i trwałego rozwoju: Ujęcie teoretyczne. Optim. Stud. Ekon. 2016, 1, 14-35. [CrossRef]

32. Holden, E.; Linnerud, K. The sustainable development area: Satisfying basic needs and safeguarding ecological sustainability. Sustain. Dev. 2007, 15, 174-187. [CrossRef]

33. Jeżowski, P. Rozwój zrównoważony i jego nowe wyzwania. Kwart. Kol. Ekon—Społecz. Stud. Pr. Szk. Gt. Handl. 2012, 2, 99-124. [CrossRef]

34. Sompolska-Rzechuła, A. Selection of the Optimal Way of Linear Ordering of Objects: Case of Sustainable Development in EU Countries. Stat.: Stat. Econ. J. 2021, 101, 24-36.

35. Bova, D.M.; Śleszyński, J. Sustainable Development Indicators: The Italian Equitable and Sustainable Well-Being Approach and its Application to the Local Level. Ekon. Środowisko 2020, 2, 32-47.

36. Bluszcz, A. Jak zmierzyć zrównoważony rozwój-alternatywy dla PKB. Zesz. Nauk. Organ. Zarz./Politech. Ślaska 2018, 118, 88-97.

37. Morgan, M.S.; Bach, M. Measuring Development-From the UN's Perspective. Hist. Political Econ. 2018, 50, 193-210. [CrossRef]

38. Skoczylas, W. Pomiar dokonań w skutecznej realizacji strategii zrównoważonego rozwoju. Ujęcie makro, mezo i mikro. Pr. Nauk. Uniw. Ekon. Wrocławiu 2018, 514, 416-427. [CrossRef] 
39. Teneta-Skwiercz, D. Wskaźniki pomiaru zrównoważonego rozwoju-Polska na tle krajów Unii Europejskiej. Pr. Nauk. Uniww. Ekon. Wroctawiu 2018, 516, 121-132. [CrossRef]

40. Śleszyński, J. Wskaźniki trwałego rozwoju na poziomie lokalnym. Optim. Stud. Ekon. 2017, 4, 39-52. [CrossRef]

41. Borychowski, M.; Staniszewski, J.; Zagierski, B. Problemy pomiaru rozwoju zrównoważonego na przykładzie wybranych wskaźników. Rocz. Ekon. Kuj.-Pomor. Szk. Wyż Bydg. 2016, 9, 28-43.

42. Urbaniec, M. Sustainable Development Indicators in Poland: Measurement and System Evaluation. Entrep. Bus. Econ. Rev. 2015, 3, 119-134. [CrossRef]

43. Śleszyński, J. Synthetic Sustainable Development Indicators: Past Experience and Guidelines. Pr. Nauk. Uniw. Ekon. Wrocławiu 2013, 308, 144-164.

44. Bartniczak, B. Moduł wskaźników zrównoważonego rozwoju w Banku Danych Lokalnych. Wiad. Stat. 2012, 9, 25-34.

45. Borys, T. Wybrane problemy metodologii pomiaru nowego paradygmatu rozwoju-polskie doświadczenia. Optim. Stud. Ekon. 2014, 3, 3-21. [CrossRef]

46. Hák, T.; Moldan, B.; Dahl, A. Sustainability Indicators: A Scientific Assessment; Scientific Committee on Problems of the Environment (SCOPE): Paris, France; Island Press: Wasington, DC, USA, 2007.

47. Wallis, A.; Richards, A.; O’Toole, K.; Mitchell, B. Measuring regional sustainability: Lessons to be learned. Int. J. Environ. Sustain. Dev. (IJESD) 2007, 6, 193-207. [CrossRef]

48. Van de Kerk, G.; Manuel, A.R. A comprehensive index for a sustainable society: The SSI—The Sustainable Society Index. Ecol. Econ. 2008, 66, 228-242. [CrossRef]

49. Bal-Domańska, B. Statystyczne bazy danych jako narzędzie monitoringu zrównoważonego rozwoju-wybrane aspekty teoretyczne. Prz. Stat. 2015, 62, 435-455.

50. Bluszcz, A. Classification of the European Union member states according to the relative level of sustainable development. Qual. Quant. 2016, 50, 2591-2605. [CrossRef]

51. Barska, A.; Jedrzejczak-Gas, J. Indicator analysis of the economic development of Polish regions in the context of the implementation of the concept of sustainable development. Eur. J. Sustain. Dev. 2019, 8, 210-221. [CrossRef]

52. Jegdrzejczak-Gas, J.; Barska, A. Assessment of the Economic Development of Polish Regions in the Context of the Implementation of the Concept of Sustainable Development-Taxonomic Analysis. Eur. J. Sustain. Dev. 2019, 8, 222-233. [CrossRef]

53. Noga, M. Co Decyduje o Rozwoju Gospodarczym. In Wzrost Gospodarczy a Innowacje; Koch, J., Ed.; Politechnika Wrocławska, Wrocławskie Centrum Transferu Technologii: Wrocław, Poland, 2008; pp. 5-13.

54. Kucharski, L.; Kwiatkowski, E.; Raczko, A. Wzrost gospodarczy w okresie długim. In Podstawy Ekonomii; Milewski, R., Kwiatkowski, E., Eds.; Wydawnictwo Naukowe PWN: Warszawa, Poland, 2018; pp. 385-418.

55. Zajączkowska, M. Polityka energetyczna Unii Europejskiej. Zesz. Nauk. Uniw. Ekon. Krakowie 2011, 852, 81-96.

56. Paska, J.; Surma, T. Rozwój energetyki odnawialnej a gospodarka. Polityka Energetyczna 2013, 16, 21-34.

57. Skoczkowski, T.; Bielecki, S. Efektywność energetyczna-polityczno-formalne uwarunkowania rozwoju w Polsce i Unii Europejskiej. Polityka Energetyczna 2016, 19, 5-20.

58. Jankiewicz, S. Wpływ bezpieczeństwa energetycznego na rozwój gospodarczy w Polsce. Pr. Nauk. Uniw. Ekon. Wrocławiu 2016, $450,251-259$.

59. Lange, O. O Socjalizmie i Gospodarce Socjalistycznej; Państwowe Wydawnictwo Naukowe: Warszawa, Poland, 1966.

60. Myrdal, G. Asian Drama, an Inquiry into the Poverty of Nations; Pantheon Books: New York, NY, USA, 1968.

61. Warczak, M. Endogeniczne i egzogeniczne czynniki rozwoju gospodarczego z perspektywy finansów gminy. Wspótczesna Gospod. 2015, 6, 111-122. Available online: http:/ / cejsh.icm.edu.pl/cejsh/element/bwmeta1.element.desklight-e9947a43-121a-41b0-a4 4b-2f93961e72a6 (accessed on 17 August 2021).

62. Marciniak, S. Makro- i Mikroekonomia. Podstawowe Problemy Wspótczesności; Wydawnictwo Naukowe PWN: Warszawa, Poland, 2021.

63. Ouedraogo, N.S. Energy consumption and economic growth: Evidence from the economic community of West African States (ECOWAS). Energy Econ. 2013, 36, 637-647. [CrossRef]

64. Begg, D.; Fisher, S.; Vernasca, G.; Dornbusch, R. Makroekonomia; Polskie Wydawnictwo Ekonomiczne: Warszawa, Poland, 2014.

65. Samuelson, P.A.; Nordhaus, W.D. Ekonomia; Dom Wydawniczy REBIS: Poznań, Poland, 2019.

66. Todaro, M.P. Economic Development in the Third World; Longman: New York, NY, USA, 1985.

67. Hunold, C.; Dryzek, J.S. Green Political Theory and the State: Context is Everything. Glob. Environ. Politics 2002, 2, 17-39. Available online: https:/ / direct.mit.edu/glep/article/2/3/17/14170/Green-Political-Theory-and-the-State-Context-is (accessed on 27 August 2021). [CrossRef]

68. Drăgoi, D. Economic growth versus economic development. Atl. Rev. Econ. 2020, 4, 1-11.

69. Porter, M.E. The Competitive Advantage of Nations; Free Press: New York, NY, USA, 1990.

70. Cieślik, E. Wybrane alternatywne sposoby mierzenia poziomu rozwoju gospodarczego. Equilibrium 2008, 1, 145-160. [CrossRef]

71. Kubiczek, A. Jak mierzyć dziś rozwój społeczno-gospodarczy krajów? Nierówności Społeczne Wzrost Gospod. 2014, 38, 40-56. Available online: https:/ / www.ur.edu.pl/storage/file/core_files/2014/7/25/b3fa067b4c630ae4cffa339b90f4d1a0/4\%20Kubiczek\% 20A.pdf (accessed on 5 August 2021). 
72. Karwat-Woźniak, B.; Chmieliński, P.; Buks, B. Przestrzenne zróżnicowanie rozwoju gospodarczego. In Polaryzacja Społeczna a Stabilność Ekonomiczna w Procesach Rozwoju Rolnictwa i Obszarów Wiejskich; Wrzochalska, A., Ed.; Instytut Ekonomiki Rolnictwa i Gospodarki Żywnościowej-Państwowy Instytut Badawczy: Warszawa, Poland, 2019; pp. 31-64.

73. Malina, A.; Malina, P. Determinanty rozwoju regionalnego Polski. Wiadomości Stat. 2005, 10, 68-79.

74. Wysocki, F. Metody Taksonomiczne w Rozpoznawaniu Typów Ekonomicznych Rolnictwa i Obszarów Wiejskich; Wydawnictwo Uniwersytetu Przyrodniczego: Poznań, Poland, 2010.

75. Lis, S. Analityczne mierniki rozwoju gospodarczego [Analytical Indices of Economic Growth]. Folia Oeconomica Crac. 1972, 12, 109-122.

76. Malizia, E.E. Economic growth and economic development: Concepts and measures. Rev. Reg. Stud. 1990, 20, 30-36.

77. Krysiński, M. Mierniki rozwoju gospodarczego-ich zróżnicowana wartość diagnostyczna i prognostyczna na przykładzie wybranych państw tzw. nowej Unii. Studia Ekon. Reg. Łódzkiego 2016, 22, 11-24. Available online: http:/ / www.krysinski.eu/wpcontent/uploads/2017/01/mierniki_PTE_nr_22.pdf (accessed on 5 August 2021).

78. Marikina, M. Gross Domestic Product or Gross National Happiness—Which Is the Better Alternative for Economic Measurement? Varazdin Development and Entrepreneurship Agency (VADEA): Varazdin, Croatia, 2018.

79. Wojciechowska-Solis, J. Assessment of the Economic Development of Regions in Poland Using Multidimensional Comparative Analysis; Varazdin Development and Entrepreneurship Agency (VADEA): Varazdin, Croatia, 2018.

80. Cheba, K.; Bak, I. Sustainable Development and its Relationships with other Directions of the Development of European Union Countries. Pr. Nauk. Uniw. Ekon. Wroctawiu 2020, 9, 29-44.

81. Spyros, R. Measuring economic development and the impact of economic globalisation. Stud. Bus. Econ. 2020, 15, 185-207. [CrossRef]

82. Stiglitz, J.E.; Sen, A.; Fitoussi, J.-P. Report by the Commission on the Measurement of Economic Performance and Social Progress 2009. Available online: https:/ / ec.europa.eu/eurostat/documents/8131721/8131772/Stiglitz-Sen-Fitoussi-Commission-report. pdf (accessed on 12 June 2021).

83. Kotyński, J. Rozwój gospodarczy Polski w drugiej dekadzie XXI wieku na tle zmian globalnych. Zesz. Nauk. Uczel. Vistula 2016, 47, 7-18. Available online: https:/ /i.vistula.edu.pl/media/docs/g6hIo7vQafRGThi7R6APjFg1.pdf (accessed on 2 July 2021).

84. Łopatka, A. Ekonomia Dobrobytu. Rachunki Narodowe w Kontekście Pomiaru Dobrobytu. Zesz. Nauk. Uniw. Szczecińskiego Wspótczesne Probl. Ekon. Glob. Lib. Etyka 2015, 11, 43-56. Available online: http://www.wzieu.pl/zn/858/08_ZN_858.pdf (accessed on 2 June 2021).

85. Stiglitz, J.E. Beyond GDP. 2018. Available online: https://www.project-syndicate.org/commentary/new-metrics-of-wellbeingnot-just-gdp-by-joseph-e-stiglitz-2018-12 (accessed on 2 June 2021).

86. Żołądek, Ł. Nie Tylko PKB. Alternatywne Wskaźniki Rozwoju; Wydawnictwo Sejmowe dla Biura Analiz Sejmowych: Warszawa, Poland, 2019. Available online: http:/ / orka.sejm.gov.pl/WydBAS.nsf/0/41AC2B6063040255C12584A90042C31B/\$file/Infos_ 265.pdf (accessed on 7 August 2021).

87. Borys, T.; Fiedor, B. Operacjonalizacja i pomiar kategorii zrównoważonego rozwoju—Przyczynek do dyskusji. In Rachunki Narodowe. Wybrane Problemy i Przykłady Zastosowań; Plich, M., Ed.; Główny Urząd Statystyczny: Warszawa, Poland; Uniwersytet Łódzki: Łódź, Poland, 2008; pp. 115-131. Available online: https:/ / stat.gov.pl/obszary-tematyczne/rachunki-narodowe/rocznerachunki-narodowe/rachunki-narodowe-wybrane-problemy-i-przyklady-zastosowan,8,2.html (accessed on 5 May 2021).

88. Wyrwa, J.; Barska, A.; Jedrzejczak-Gas, J.; Sinicakova, M. Industry 4.0 and social development in the aspect of sustainable development: Relations in EC countries. Eur. Res. Stud. J. 2020, 23, 1068-1097. Available online: https://www.um.edu.mt/ library / oar/handle/123456789/76037 (accessed on 25 August 2021). [CrossRef]

89. Hellwig, Z. Zastosowania metody taksonomicznej do typologicznego podziału krajów ze względu na poziom ich rozwoju i strukture wykwalifikowanych kadr. Przeglad Stat. 1968, 4, 307-327.

90. Hwang, C.L.; Yoon, K. Multiple Attribute Decision Making: Methods and Applications; Springer: Berlin, Germany, 1981.

91. A European Union Strategy for Sustainable Development. Commission's Proposal to the Gothenburg European Council; COM (2001) 264 final; Commission of the European Communities: Brussels, Belgium, 2001.

92. Europe 2020-A Strategy for Smart, Sustainable and Inclusive Growth; Com (2010) 2020; European Commission: Brussels, Belgium, 2010.

93. AGENDA 21, United Nations Conference on Environment \& Development Rio de Janerio, Brazil, 3-14 June 1992. Available online: https:/ / sustainabledevelopment.un.org/content/documents/Agenda21.pdf (accessed on 25 August 2021).

94. Report of the United Nations Conference on Environment and Development, 12 August 1992, A/CONF.151/26 (Vol. I). Available online: https:/ / www.un.org/en/development/desa/population/migration/generalassembly/docs/globalcompact/A_CONF. 151_26_Vol.I_Declaration.pdf (accessed on 25 August 2021).

95. Lee, B.X.; Kjaerulf, F.; Turner, S.; Cohen, L.; Donnelly, P.D.; Muggah, R.; Davis, R.; Realini, A.; Kieselbach, B.; MacGregor, L.S.; et al. Transforming Our World: Implementing the 2030 Agenda through Sustainable Development Goal Indicators. J. Public Health Policy 2016, 37, 13-31. [CrossRef]

96. Colglazier, W. Sustainable development agenda: 2030. Science 2015, 349, 1048-1050. [CrossRef]

97. Diaz-Sarachaga, J.M.; Jato-Espino, D.; Castro-Fresno, D. Is the Sustainable Development Goals (SDG) index an adequate framework to measure the progress of the 2030 Agenda? Sustain. Dev. 2018, 26, 663-671. [CrossRef] 
98. Remeikienè, R.; Belas, J.; Kliestik, T.; LubosSmreka, L. Quantitative Assessment of Dynamics of Economic Development in the Countries of the European Union. Technol. Econ. Dev. Econ. 2020, 26, 933-946. [CrossRef]

99. Report of the World Summit on Sustainable Development, Johannesburg, South Africa, 26 August-4 September 2002, United Nations, A/CONF.199/20. Available online: https://undocs.org/pdf?symbol=en/A/Conf.199/20 (accessed on 25 August 2021).

100. The Future We Want, Outcome Document of the United Nations Conference on Sustainable Development, Rio de Janeiro, Brazil, 20-22 June 2012. Available online: https:/ / sustainabledevelopment.un.org/content/documents/733FutureWeWant.pdf (accessed on 25 August 2021).

101. Balicki, A. Statystyczna Analiza Wielowymiarowa i Jej Zastosowanie Społeczno-Ekonomiczne; Wydawnictwo Uniwersytetu Gdańskiego: Gdańsk, Poland, 2009.

102. Młodak, A. Analiza Taksonomiczna w Statystyce Regionalnej; Wydawnictwo Difin: Warszwa, Poland, 2006.

103. Borys, T. Metody normowania cech w statystycznych badaniach porównawczych. Przeglad Stat. 1978, 2, $227-239$.

104. Walesiak, M. Uogólniona Miara Odległości GDM w Statystycznej Analizie Wielowymiarowej z Wykorzystaniem Programu R; Wydawnictwo Uniwersytetu Ekonomicznego: Wrocław, Poland, 2011.

105. Tomaszewski, K. Polityka energetyczna Unii Europejskiej w kontekście problematyki bezpieczeństwa gospodarczego. Przeglą Politol. 2018, 1, 133-145. [CrossRef] 